\title{
Parasites of the genus Nosema, Crithidia and Lotmaria in the honeybee and bumblebee populations: a case study in India
}

\author{
V.Y. Vavilova ${ }^{1}$ @, I. Konopatskaia ${ }^{1,2}$, S.L. Luzyanin ${ }^{3}$, M. Woyciechowski ${ }^{4}$, A.G. Blinov ${ }^{1,5}$ \\ ${ }^{1}$ Institute of Cytology and Genetics SB RAS, Novosibirsk, Russia \\ ${ }^{2}$ Novosibirsk State University, Novosibirsk, Russia \\ 3 Institute of Biology, Ecology and Natural Resources, Kemerovo State University, Kemerovo, Russia \\ ${ }^{4}$ Institute of Environmental Sciences, Jagiellonian University, Krakow, Poland \\ ${ }^{5}$ Institute of Systematics and Ecology SB RAS, Novosibirsk, Russia
}

\begin{abstract}
The populations of honeybees and bumblebees have been decreasing around the world in the recent decades. A variety of pathogens and parasites, including bacteria, fungi, protozoa, nematodes, mites and insects play significant role in honeybee and bumblebee colonies loss. Parasites of the genus Nosema (Microsporidia: Nosematidae) and the genera Crithidia and Lotmaria (Kinetoplastida:Trypanosomatidae) have a significant negative impact on honeybee and bumblebee colonies. Recent studies of nuclear DNA markers of these parasites allowed to describe new species and genetic variants. The aim of this study was to investigate the Microsporidia (Nosema spp.) and Trypanosomatidae (Crithidia spp. and Lotmaria passim) prevalence and genetic diversity in honeybee and bumblebee populations of Indian territories that haven't been studied before. In total 119 specimens of 4 honeybee and 5 bumblebee species were analyzed in this study. The prevalence of parasites in honeybee and bumblebee populations of the two Indian states (Jammu and Kashmir, Karnataka) were identified using PCR with primers specific for the ribosomal RNA genes cluster of Nosema, Crithidia and Lotmaria species. Co-infection by microsporidian and trypanosomatid parasites was detected in several honeybee and bumblebee specimens from Jammu and Kashmir state. Comparative analysis of ribosomal RNA genes sequences showed that honeybee samples from India studied were infected by N. bombi, N. ceranae and L. passim. Bumblebee populations were infected by Nosema D, Crithidia bombi and Crithidia expoeki. No honeybee's specimen with trypanosomatid infection was found in Karnataka state. For the first time N. bombi infection was detected in the honeybee population. The studies of distribution of microsporidia and trypanosomatid parasites among the honeybee and bumblebee populations all over the World were summarized and supplemented.
\end{abstract}

Key words: honeybees; bumblebees; infection; ribosomal RNA genes; Nosema spp.; Crithidia spp.; Lotmaria passim.

\section{Паразитические организмы родов Nosema, Crithidia и Lotmaria в популяциях пчел и шмелей: исследование в Индии}

В.Ю. Вавилова ${ }^{1} \otimes$, И.А. Конопацкая ${ }^{1,2}$, С.А. Аузянин ${ }^{3}$, М. Войцеховский ${ }^{4}$, А.Г. БАинов ${ }^{1,5}$

\footnotetext{
${ }^{1}$ Федеральный исследовательский центр Институт цитологии и генетики Сибирского отделения Российской академии наук, Новосибирск, Россия

${ }^{2}$ Новосибирский национальный исследовательский государственный университет, Новосибирск, Россия

${ }^{3}$ Институт биологии, экологии и природных ресурсов, Кемеровский государственный университет, Кемерово, Россия

${ }^{4}$ Институт наук об окружающей среде, Ягеллонский университет, Краков, Польша

${ }^{5}$ Институт систематики и экологии животных Сибирского отделения Российской академии наук, Новосибирск, Россия
}

В последние десятилетия наблюдается резкое снижение численности популяций медоносных пчел и шмелей на территории большинства стран мира. Вклад в снижение численности данных опылителей вносят различные паразитические организмы (бактерии, грибы, простейшие, нематоды, клещи и насекомые). Паразиты рода Nosema (Microsporidia: Nosematidae) и родов Crithidia и Lotmaria (Kinetoplastida: Trypanosomatidae) оказывают значительное негативное влияние на численность медоносных пчел и шмелей. В недавних исследованиях, проведенных с использованием ядерных ДНК-маркеров, были описаны новые виды и генетические варианты данных паразитов. Целью настоящей работы являлось установление уровня зараженности медоносных пчел и шмелей микроспоридиями (Nosema spp.) и трипаносоматидами (Crithidia spp. и Lotmaria passim), а также изучение генетической вариабельности этих паразитов на ранее не исследованной территории Индии. В работе проанализировано 119 образцов из четырех видов медоносных пчел и пяти видов шмелей. Уровни зараженности популяций пчел и шмелей паразитическими организмами на территории двух штатов (Джамму и Кашмир, Карнатака) были определены с помощью полимеразной цепной реакции с праймерами, специфичными к кластеру генов рибосомной PHK Nosema, Crithidia и Lotmaria. Совместное заражение популяций медоносных пчел и шмелей микроспоридиями и трипаносоматидами было зафиксировано на территории штата Джамму и Кашмир. В результате сравнительного анализа нуклеотидных последовательностей кластера генов рибосомной РНК установлено, что в популяциях медоносных пчел на территории Индии были представлены N. bombi, N. ceranae и L. passim. Популяции шмелей были поражены микроспоридией Nosema D и трипаносоматидами Crithidia bombi и Crithidia 
expoeki. В образцах медоносных пчел, собранных на территории штата Карнатака, паразиты родов Crithidia и Lotmaria не выявлены. В популяции медоносных пчел впервые выявлена микроспоридия N. bombi. Данные о распространении микроспоридий и трипаносоматид в популяциях медоносных пчел и шмелей по всему миру были обобщены и дополнены.

Ключевые слова: медоносные пчелы; шмели; заражение; гены рибосомной PHК; Nosema spp.; Crithidia spp.; Lotmaria passim.

\section{HOW TO CITE THIS ARTICLE:}

Vavilova V.Y., Konopatskaia I., Luzyanin S.L., Woyciechowski M., Blinov A.G. Parasites of the genus Nosema, Crithidia and Lotmaria in the honeybee and bumblebee populations: a case study in India. Vavilovskii Zhurnal Genetiki i Selektsii =Vavilov Journal of Genetics and Breeding. 2017;21(8):943-951. DOI 10.18699/VJ17.317

M icrosporidia of the genus Nosema (Microsporidia: Nosematidae) and trypanosomatid parasites of the genera Crithidia and Lotmaria (Kinetoplastida: Trypanosomatidae) have a negative impact on the honeybees and bumblebees colonies fitness (Schmid-Hempel, 2001; Brown et al., 2003; Higes et al., 2008; Hornitzky, 2008; Yourth et al., 2008; Ravoet et al., 2013).

Nosema and Tubulinosema species represent the obligate intracellular spore forming organisms that are related to the Fungi (Han, Weiss, 2017). Two microsporidium species, Nosema ceranae (Fries et al., 1996) and Nosema apis (Zander, 1909), are known to infect honeybees. Nosema bombi is another parasite belonging to the phylum Microsporidia which is widespread in the bumblebee populations (Fantham, Porter, 1914). Analysis of standard nuclear DNA markers of $N$. bombi in bumblebee colonies from USA, Russia, China and several European countries revealed new genetic variants of the parasite (Fries et al., 2001; Tay et al., 2005; Szentgyörgyi et al., 2011; Cordes et al., 2012; Li et al., 2012; Vavilova et al., 2015). Three new Nosema variants (A, B, and C) isolated from bumblebees in China were suggested to be genetic variants of N. ceranae (Li et al., 2012; Vavilova et al., 2015). All detected genetic variants of Nosema species did not receive the status of separate species.

Another microsporidium species Tubulinosema pampeana (Microsporidia: Tubulinosematidae) was described for the first time in Bombus araratus individuals from Argentine (Plischuk et al., 2015). Currently, there are no cases of T. pampeana infections in other regions.

Crithidia and Lotmaria species are the protozoan flagellated trypanosomatid parasites of honeybees and bumblebees. For a long time Crithidia mellificae (Langridge, McGhee, 1967) was the only Trypanosomatidae species described for the Apis mellifer $a$ and it was poorly investigated. Resent identification of several DNA markers of the American honeybees parasites revealed their high genetic diversity (Cox-Foster et al., 2007; vanEngelsdorp et al., 2009; Runckel et al., 2011; Cornman et al., 2012). After detailed analysis of trypanosome stains the C. mellificae SF was redesignated as Lotmaria passim. Therefore at the moment two stains of C. mellificae (designated as ATCC 30254 and ATCC 30862) and two stains of Lotmaria passim (designated as BRL and SF) for honeybee populations are described (Schwarz et al., 2015). Trypanosomatid Crithidia bombi (Lipa, Triggiani, 1988) infecting bumblebees is highly researched (Schmid-Hempel, Reber Funk, 2004; Meeus et al., 2010; Schmid-Hempel, Tognazzo, 2010). Microsatellite data showed that several C. bombi genotypes circulates in bumblebee populations from Switzerland, Argentina and Chile (Schmid-Hempel, Reber Funk, 2004; Schmid-Hempel et al., 2011, 2014). Recently two new Crithidia species, Crithidia expoeki and Crithidia mexicana, have been identified in bumblebees from North America and Mexica, respectively (Schmid-Hempel, Tognazzo, 2010; Gallot-Lavallée et al., 2016).

Microsporidian and trypanosomatid parasites described above have a negative impact on the honeybees and bumblebees fitness. The parasites cause the rapid honeybees and bumblebees loss at both individual and colony levels (SchmidHempel, 2001; Brown et al., 2003; Higes et al., 2008; Hornitzky, 2008; Yourth et al., 2008; Ravoet et al., 2013).

Thus, investigation of these parasites in host populations from new geographical regions allows to characterize new genetic variants and describe it's specific distribution. Despite the high importance of honeybees and bumblebees for the economy of India no studies of their parasites have been performed so far. In this study the diversity of Nosema, Crithidia, and Lotmaria parasites from honeybees and bumblebees in an unexplored regions of India, states Jammu and Kashmir and Karnataka were analyzed.

\section{Materials and methods}

Sample collection, DNA extraction, PCR amplification, and sequencing. 80 samples of honeybee species (A. cerana, A. dorsata, A. florea and A. mellifera) were collected in two Indian states (Jammu and Kashmir, Karnataka) in May and June, 2007, respectively (Fig. 1, Table). 39 bumblebee specimens of B. asiaticus, B. lucorum, B. rufofasciatus, B. simillimus and $B$. trifasciatus species were collected in Jammu and Kashmir state in May, 2007 (see Fig. 1, Table).

All samples were obtained by entomological sweep nets, identified to the species level in the field and preserved in $70 \%$ ethanol. Total DNA were extracted from abdomens of the specimens fixed in ethanol using DNeasy Blood and Tissue Kit (QIAGEN) according to the manufacturer's protocol.

The standard sets of primers and PCR conditions were used for PCR amplification of small subunit ribosomal RNA (SSU rRNA), internal transcribed spacer (ITS) and large subunit ribosomal RNA (LSU rRNA) genes of Nosema spp. and Tubulinosema spp. (Tay et al., 2005; Szentgyörgyi et al., 2011) and 18S rRNA genes of Crithidia spp. and L. passim (Meeus et al., 2010; Arismendi et al., 2016). Polymerase chain reactions (PCR) were performed in $20 \mu \mathrm{l}$ volume containing $0.1 \mu \mathrm{g}$ of genomic DNA, $10 \mathrm{mM}$ Tris- $\mathrm{HCl}(\mathrm{pH} 8.9), 1 \mathrm{mM}$ $\left(\mathrm{NH}_{4}\right)_{2} \mathrm{SO}_{4}, 1.5 \mathrm{mM} \mathrm{MgCl} 2,200 \mu \mathrm{M}$ of each of four dNTPs, $0.5 \mu \mathrm{M}$ primers, and 2.5 units of Taq DNA polymerase. The PCR products were analyzed in $1.2 \%$ agarose gel electrophoresis and extracted from gel with a QIAquick Gel Extraction Kit (QIAGEN). From 40 ng to 200 ng of each PCR product 


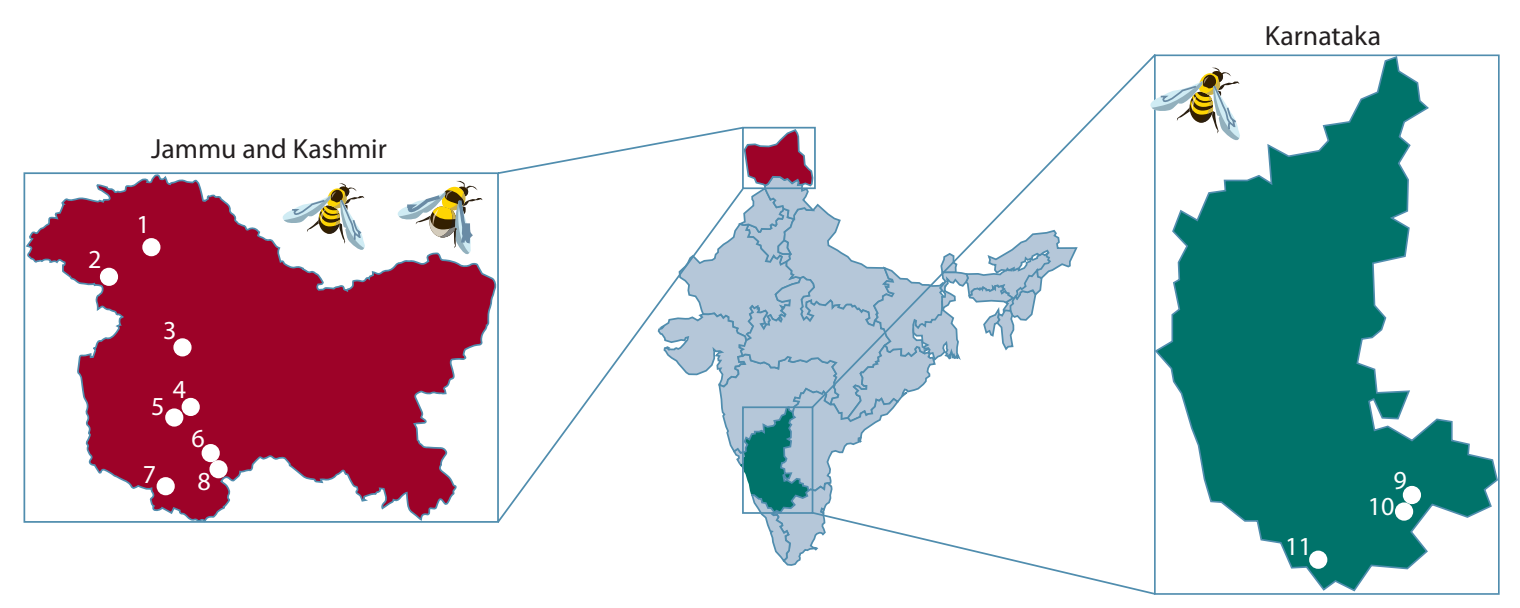

Fig. 1. Map of Indian states with collection sites designation. Collection sites are correlated with the Table.

Collection sites and list of honeybee and bumblebee species used in this study. The site areas are designated according to the Fig. 1

\begin{tabular}{|c|c|c|c|c|c|c|}
\hline \multirow[t]{2}{*}{ Indian state } & \multirow[t]{2}{*}{ Site } & \multirow{2}{*}{$\begin{array}{l}\text { Coordinates } \\
\text { of sites }\end{array}$} & \multirow{2}{*}{$\begin{array}{l}\text { Species of genus } \\
\text { Apis and Bombus }\end{array}$} & \multirow{2}{*}{$\begin{array}{l}\text { Specimen } \\
\text { number }\end{array}$} & \multicolumn{2}{|c|}{ Number of infected specimens (positive results of $P C R$ ) } \\
\hline & & & & & $\begin{array}{l}\text { Nosema spp./ } \\
\text { Tubulinosema spp. }\end{array}$ & $\begin{array}{l}\text { Crithidia spp./ } \\
\text { Lotmaria passim }\end{array}$ \\
\hline \multirow{10}{*}{$\begin{array}{l}\text { Jammu } \\
\text { and Kashmir }\end{array}$} & \multirow[t]{2}{*}{1} & \multirow{2}{*}{$\begin{array}{l}34^{\circ} 08^{\prime} 50.2^{\prime \prime} \mathrm{N} \\
74^{\circ} 53^{\prime} 01.2^{\prime \prime} \mathrm{E}\end{array}$} & Apis cerana Fabricius, 1793 & 4 & $2 / 0$ & $0 / 2$ \\
\hline & & & Apis mellifera Linnaeus, 1758 & 13 & $7 / 0$ & $0 / 5$ \\
\hline & 2 & $\begin{array}{l}34^{\circ} 01^{\prime} 57.2^{\prime \prime} \mathrm{N} \\
74^{\circ} 21^{\prime} 50.5^{\prime \prime} \mathrm{E}\end{array}$ & A. cerana & 2 & $0 / 0$ & $0 / 0$ \\
\hline & \multirow[t]{2}{*}{3} & \multirow{2}{*}{$\begin{array}{l}33^{\circ} 32^{\prime} 09.2^{\prime \prime} \mathrm{N}, \\
75^{\circ} 14^{\prime} 57.8^{\prime \prime} \mathrm{E}\end{array}$} & A. cerana & 1 & $0 / 0$ & $0 / 0$ \\
\hline & & & A. mellifera & 5 & $0 / 0$ & $0 / 1$ \\
\hline & 4 & $\begin{array}{l}33^{\circ} 07^{\prime} 38.1^{\prime \prime} \mathrm{N} \\
75^{\circ} 22^{\prime} 19.2^{\prime \prime} \mathrm{E}\end{array}$ & A. mellifera & 9 & $3 / 0$ & $0 / 1$ \\
\hline & 6 & $\begin{array}{l}32^{\circ} 59^{\prime} 38.0^{\prime \prime} \mathrm{N} \\
75^{\circ} 42^{\prime} 10.9^{\prime \prime} \mathrm{E}\end{array}$ & A. cerana & 7 & $0 / 0$ & $0 / 0$ \\
\hline & \multirow[t]{3}{*}{7} & \multirow{3}{*}{$\begin{array}{l}32^{\circ} 43^{\prime} 07.4^{\prime \prime} \mathrm{N} \\
74^{\circ} 51^{\prime} 59.1^{\prime \prime} \mathrm{E}\end{array}$} & A. cerana & 2 & $0 / 0$ & $0 / 0$ \\
\hline & & & Apis dorsata Fabricius, 1793 & 19 & $4 / 0$ & $0 / 1$ \\
\hline & & & Apis florea Fabricius, 1787 & 1 & $0 / 0$ & $0 / 0$ \\
\hline \multirow[t]{5}{*}{ Karnataka } & \multirow[t]{3}{*}{9} & \multirow{3}{*}{$\begin{array}{l}13^{\circ} 01^{\prime} 09.0^{\prime \prime} \mathrm{N} \\
77^{\circ} 34^{\prime} 07.0^{\prime \prime} \mathrm{E}\end{array}$} & A. cerana & 6 & $1 / 0$ & $0 / 0$ \\
\hline & & & A. dorsata & 2 & $1 / 0$ & $0 / 0$ \\
\hline & & & A. florea & 2 & $1 / 0$ & $0 / 0$ \\
\hline & 10 & $\begin{array}{l}12^{\circ} 53^{\prime} 05.8^{\prime \prime} \mathrm{N} \\
77^{\circ} 28^{\prime} 21.5^{\prime \prime} \mathrm{E}\end{array}$ & A. mellifera & 5 & $0 / 0$ & $0 / 0$ \\
\hline & 11 & $\begin{array}{l}12^{\circ} 01^{\prime} 07.4^{\prime \prime} \mathrm{N} \\
76^{\circ} 06^{\prime} 06.6^{\prime \prime} \mathrm{E}\end{array}$ & A. dorsata & 2 & $1 / 0$ & $0 / 0$ \\
\hline \multicolumn{4}{|c|}{ Total specimen number } & 80 & $20 / 0$ & $0 / 10$ \\
\hline \multirow[t]{8}{*}{$\begin{array}{l}\text { Jammu and } \\
\text { Kashmir }\end{array}$} & 1 & $\begin{array}{l}34^{\circ} 08^{\prime} 50.2^{\prime \prime} \mathrm{N} \\
74^{\circ} 53^{\prime} 01.2^{\prime \prime} \mathrm{E}\end{array}$ & Bombus simillimus Smith, 1852 & 8 & $0 / 0$ & $2 / 0$ \\
\hline & \multirow[t]{3}{*}{2} & \multirow{3}{*}{$\begin{array}{l}34^{\circ} 01^{\prime} 57.2^{\prime \prime} \mathrm{N} \\
74^{\circ} 21^{\prime} 50.5^{\prime \prime} \mathrm{E}\end{array}$} & Bombus asiaticus Morawitz, 1875 & 2 & $0 / 0$ & $1 / 0$ \\
\hline & & & Bombus lucorum Linnaeus, 1761 & 1 & $0 / 0$ & $0 / 0$ \\
\hline & & & Bombus rufofasciatus Smith, 1852 & 1 & $0 / 0$ & $0 / 0$ \\
\hline & 4 & $\begin{array}{l}33^{\circ} 07^{\prime} 38.4^{\prime \prime} \mathrm{N} \\
75^{\circ} 22^{\prime} 19.5^{\prime \prime} \mathrm{E}\end{array}$ & Bombus trifasciatus Smith, 1852 & 3 & $2 / 0$ & $0 / 0$ \\
\hline & 5 & $\begin{array}{l}33^{\circ} 05^{\prime} 09.9^{\prime \prime} \mathrm{N} \\
75^{\circ} 19^{\prime} 49.2^{\prime \prime} \mathrm{E}\end{array}$ & B. trifasciatus & 5 & $2 / 0$ & $2 / 0$ \\
\hline & \multirow[t]{2}{*}{8} & \multirow{2}{*}{$\begin{array}{l}32^{\circ} 57^{\prime} 11.1^{\prime \prime} \mathrm{N} \\
75^{\circ} 43^{\prime} 31.5^{\prime \prime} \mathrm{E}\end{array}$} & B. asiaticus & 16 & $0 / 0$ & $7 / 0$ \\
\hline & & & B. trifasciatus & 3 & $0 / 0$ & $0 / 0$ \\
\hline \multicolumn{4}{|c|}{ Total specimen number } & 39 & $4 / 0$ & $12 / 0$ \\
\hline
\end{tabular}



$p=0.95$

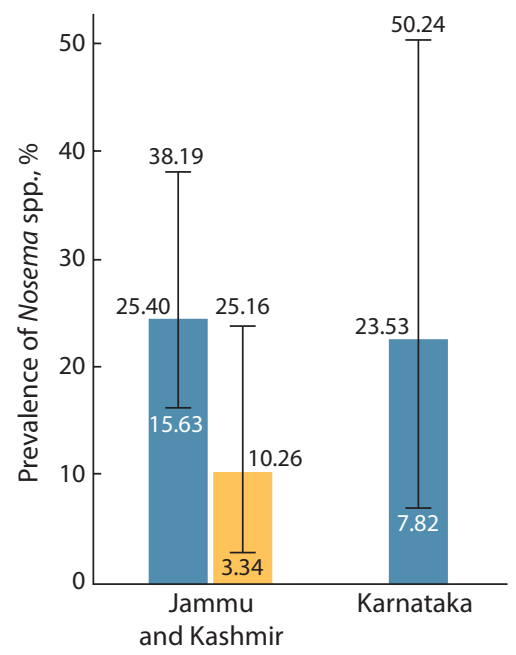

$b$
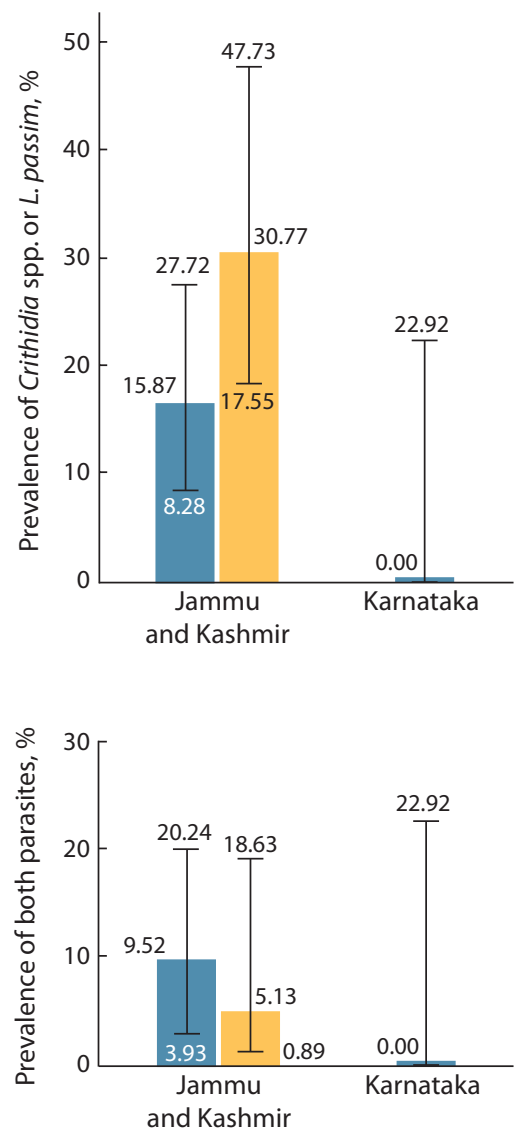

Fig. 2. Prevalence of Nosema spp. (a), Crithidia spp. or L. passim (b) infection and co-infection of all parasites (c) in honeybee and bumblebee populations from Jammu and Kashmir and Karnataka states.

Bars represent confidence intervals defined by chisquare test $(p=0.95)$ in STATISTICA. The studied parasites were characterized by low host-specificity; thus, their prevalence was calculated as percentage of the infected specimens to the total number of honeybee or bumblebee specimens in each sampling location. was used in a $10-\mu$ l cycle sequencing reaction with the BigDye ${ }^{\circledR}$ Terminator Kit (Applied Biosystems) and analyzed on an ABI 3130XL Genetic Analyser (Applied Biosystems) at the SB RAS Genomics Core Facility (Novosibirsk, Russia, http:// sequest.niboch.nsc.ru). The partial SSU rRNA sequences of $N$. bombi and N. ceranae were deposited in the European Nucleotide Archive (ENA) under accession numbers HG321408-HG321411 and LT548980-LT548999. The obtained SSU rRNA, ITS2, and LSU rRNA gene sequences of Nosema spp. were deposited to GenBank under accession numbers KF188752- KF188755. The partial sequences of $18 \mathrm{~S}$ rRNA gene from Crithidia spp. and L. passim were placed in GenBank under accession numbers KX151671-KX151702.

Parasite prevalence. The prevalence of microsporidia and trypanosomatid parasites was calculated as percentage of the infected specimens to the total number of honeybee or bumblebee specimens in each sampling sites. Confidence intervals for parasite prevalence were defined using STATISTICA by chi-square test.

Comparative and phylogenetic analyses. Logical search was performed to identify rRNA genes sequences from insects parasites of the phylum Microsporidia and family Trypanosomatidae available from the United States National Center for Biotechnology Information. Nucleotide sequences alignments were performed by ClustalW (Larkin et al., 2007) and improved by MUSCLE algorithm (Edgar, 2004) in Unipro UGENE software (Okonechnikov et al., 2012) (http://ugene. unipro.ru) for each parasite group. Phylogenetic analyses were performed using the Neighbor-Joining (NJ) method in MEGA 6.0 and Maximum Likelihood (ML) method in PhyML 3.0 (Guindon, Gascuel, 2003; Tamura et al., 2013). Statistical support for the NJ and ML trees was evaluated by bootstrapping, 100 replications for the ML method and 1,000 replications for the NJ method (Felsenstein, 1985).

\section{Results and discussion}

Prevalence of parasite infection in honeybee and bumblebee populations

We studied 80 honeybee and 39 bumblebee specimens collected in two Indian states. Nosema spp. were detected by PCR amplification with primers specific to SSU rRNA sequence. Nosema spp. were discovered in 20 honeybee specimens from all investigated honeybee species and 4 bumblebee specimens of $B$. trifasciatus. The prevalence of Nosema spp. in honeybee populations was 25 and $24 \%$ in Jammu and Kashmir, and Karnataka states, respectively (Fig. 2, a). In Jammu and Kashmir state the prevalence of Nosema spp. in bumblebee population was $10 \%$.

The trypanosomatid parasites were identified by PCR amplification with primers specific to $18 \mathrm{~S}$ rRNA sequence in 10 honeybee and 12 bumblebee specimens. A. cerana, A. dorsata, A. mellifera, B. asiaticus, B. simillimus and B. trifasciatus species were infected. In Jammu and Kashmir state the prevalence of trypanosomatid parasites was 16 and $31 \%$ in honeybee and bumblebee populations, respectively (Fig. 2,b). No infected honeybee specimens were found in Karnataka state.

Co-infection by Nosema spp. and one of the trypanosomatid parasites (Crithidia spp. or L. passim) was detected in 6 honeybee (A. cerana and A. mellifera) and 2 bumblebee (B. trifasciatus) specimens in Jammu and Kashmir state (Fig. 2, c).

\section{Genetic diversity of Nosema spp. in honeybee and bumblebee populations} Comparative analyses of the SSU rRNA sequences of Nosema spp. Totally, we obtained 24 nucleotide sequences of Nosema spp. SSU rRNA gene from honeybees and bumblebees (see Table). The results of the comparative analysis showed that 13 out of 20 sequences from honeybee specimens were identical to $N$. bombi SSU rRNA sequences (KF002566, HG321391, KF188769, JN872234, and JN872233). $N$. bombi was described for bumblebees only. The remaining 7 sequences were identical to SSU rRNA of N. ceranae (KF640602, JX205150).

Previously Nosema species were considered to be the host specific parasites. $N$. apis infected only the European honeybee A. mellifera, while $N$. ceranae was a specific parasite for the Asian honeybee $A$. cerana (Smith, 2012). In the recent years $N$. ceranae was identified in A. mellifera and some bumblebee species in the different parts of the world. Moreover, some stains of $N$. ceranae are predicted to replace $N$. apis in populations of $A$. mellifera honeybees (Chen, Huang, 2010; 

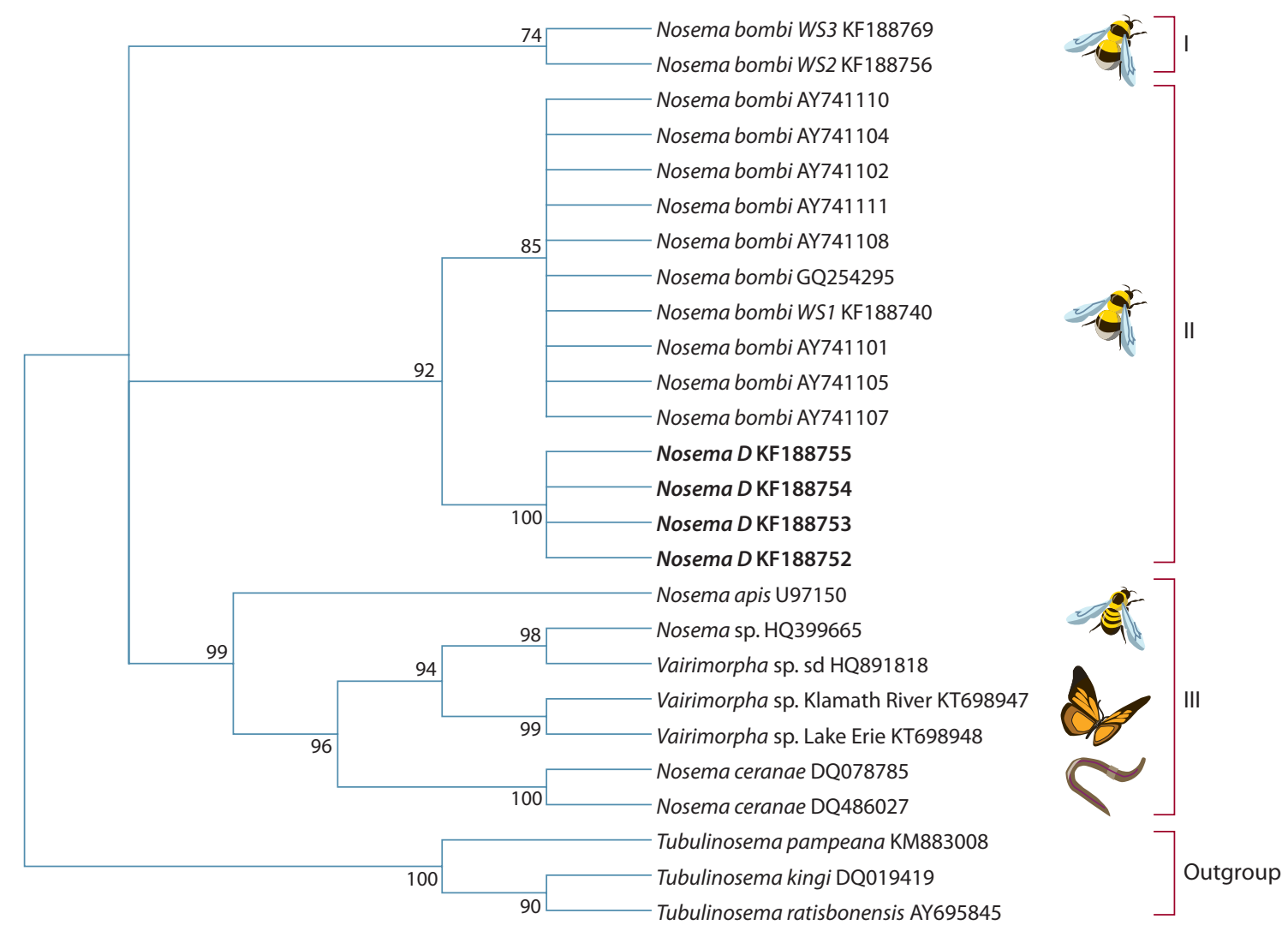

Fig. 3. Neighbor-joining (NJ) phylogenetic tree was based on SSU rRNA, ITS2, and the partial LSU rRNA nucleotide sequences of several N. bombi genetic variants, Nosema spp. and Vairimorpha spp. from various insects and annelids available from GenBank. Tubulinosema spp. were used as outgroup.

Statistical support was evaluated by bootstrapping (1000 replications). The nodes with bootstrap values over $50 \%$ are indicated.

Martín-Hernández et al., 2012). In this study a bumblebee parasite $N$. bombi was identified in honeybees from Jammu and Kashmir and Karnataka states, thus additionally refuting the assumption of the host specificity of Nosema species.

All Nosema spp. SSU rRNA sequences from infected bumblebee specimens were almost identical to Nosema $D$ sequences (JN872219-JN872229) (Li et al., 2012). A distinguish is only a single nucleotide substitution. No other Nosema as well as Tubulinosema species were found in bumblebees in this study (see Table).

Comparative and phylogenetic analyses of SSU rRNA, ITS2 and partial LSU rRNA sequences from Nosema spp. To expand information about Nosema $D$ we obtained SSU rRNA, ITS2, and partial LSU rRNA sequences for four B. trifasciatus specimens. Sequences of Vairimorpha spp., N. bombi, N. ceranae, N. apis, and Nosema sp. from Pieris rapae from GenBank, as well as the obtained sequences were used for phylogenetic analysis. Sequences of several Tubulinosema species were taken as an outgroup. Phylogenetic tree built by the NJ method is presented in Fig. 3 .

The phylogenetic tree was divided on outgroup and three clusters (see Fig. 3). The outgroup was presented by sequences of $T$. pampeana, which were described as parasite of $B$. araratus from South America and two parasites of Drosophila spp. (T. ratisbonensis and T. kingi). The first cluster (I) consists of sequences of N. bombi WS2 and N. bombi WS 3 that were previously described in populations of bumblebee from West Siberia (Vavilova et al., 2015). The second cluster (II) includes two clades. The sequences of $N$. bombi previously identified from the Europe, USA and West Siberia formed the first clade (Tay et al., 2005; Sokolova et al., 2010; Szentgyörgyi et al., 2011). The second clade consists of the newly identified Nosema $D$ sequences. The third cluster (III) is also split into two clades. Sequence of $N$. apis, obtained from A. mellifera apiary specimens in New Zealand (Gatehouse, Malone, 1998), is in the first clade of the third cluster. The second clade of this cluster consists of sequences of several Vairimorpha spp. from Bombyx mori and Manayunkia speciosa (Liu et al., 2012; Malakauskas et al., 2015); sequences of $N$. ceranae from Taiwan honeybees (Huang at al., 2007); and sequence of unspecified Nosema from Pieris rapae (Chen et al., 2012). Thus, the analysis of complete SSU rRNA, ITS2 and partial LSU rRNA gene sequences confirmed that Nosema $D$ is a genetic variant of $N$. bombi and distributed in the bumblebee populations at least in China and India.

\section{Genetic diversity of Crithidia spp. and Lotmaria passim} in honeybee and bumblebee populations

Comparative analyses of the $18 \mathrm{~S}$ rRNA sequences of Crithidia spp. and Lotmaria passim. We obtained 10 and 12 nucleotide sequences of $18 \mathrm{~S}$ rRNA gene of trypanosomatid parasites in honeybees and bumblebees, respectively 


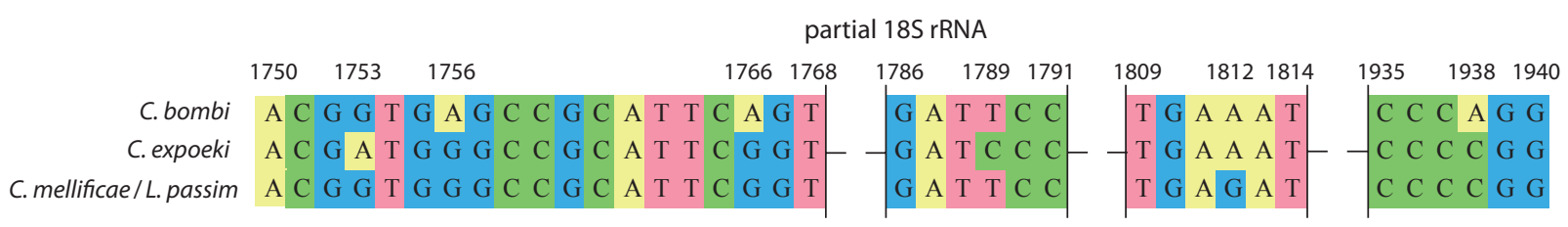

Fig. 4. Alignment of partial $18 \mathrm{~S}$ rRNA gene sequences of C. bombi, C. expoeki and C. mellificae/L. passim specified from honeybee and bumblebee specimens in this study.

Nucleotide positions are indicated according to Crithidia fasciculata sequence (Y00055) of full-length rRNA gene cluster.

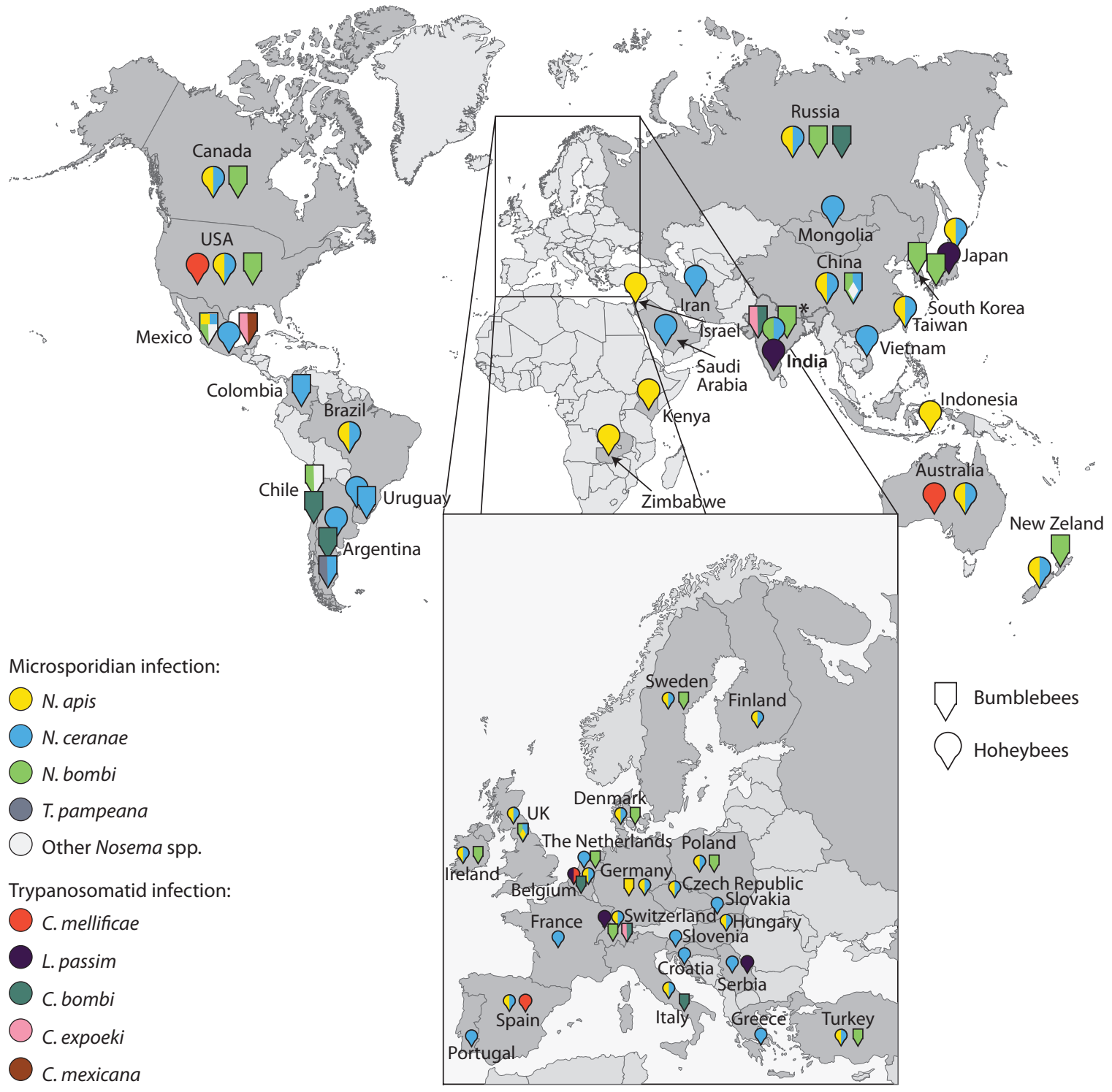

Fig. 5. World map of microsporidian and trypanosomatid distributions across the honeybee and bumblebee populations.

* Nosema D, which was determined in bumblebee populations from China (Li et al., 2012) and from India (the present study).

(see Table). The results of comparative analysis showed that nine of infected bumblebee specimens refer to $C$. expoeki (KM980187) and three others refer to C. bombi (FN546181, KM980184, KM980185). The distinguish between C. bombi and $C$. expoeki sequences amounted five nucleotide substitutions (Fig. 4).
All ten 18S rRNA gene sequences were identical and they could belong to either $C$. mellificae or $L$. passim parasites. Sequences of $C$. mellificae/L. passim differ in 4 and 3 nucleotide substitutions from C. bombi and C. expoeki, respectively (see Fig. 4). Using the primers for $18 \mathrm{~S}$ rRNA specific to L. passim and to C. mellificae (Arismendi et al., 2016) on the next 
step, we proved that all the obtained sequences belonged to L. passim (KJ713378, KM980188, KT252553, KX953206).

Summarizing the data about microsporidian and trypanosomatid parasites in honeybee and bumblebee population from India, we identified that two $A$. cerana and one $A$. mellifera specimens were co-infected by $N$. ceranae and L. passim; three specimens of $A$. mellifera were infected by both $N$. bombi and L. passim. Co-infection by Nosema $D$ and $C$. expoeki in bumblebee populations was established in two B. trifasciatus specimens. No cases of Nosema $D$ and $C$. bombi co-infection were found in this study.

Co-infection by $N$. ceranae and L. passim was also previously established in honeybee samples from Switzerland (Tritschler et al., 2017). Infection of both $N$. ceranae and C. mellificae parasites was described for honeybees from Belgian apiaries (Ravoet et al., 2013) (see Fig. 4). Nevertheless, sequences of $C$. mellificae $18 \mathrm{~S}$ rRNA, identified by Ravoet et al. (2013), were identical for C. mellificae and L. passim. Thus, these data should be clarified. Gallot-Lavallée et al. (2016) investigated co-infection by Nosema spp. and Crithidia spp. in the bumblebee populations from Mexico and established the cases of shared parasite infection (Fig. 5). However, species of Nosema and Crithidia genera found in infected bumblebee samples were not specified. Our data about co-infection of honeybee and bumblebee specimens by microsporidia and trypanosomatid parasites coincide with previously described studies. For the first time $N$. bombi/L. passim and $N$. bombi/C. expoeki co-infection were detected.

\section{Geographic distribution of Nosema spp., Crithidia spp.} and $L$. passim in honeybee and bumblebee populations The results of this study supplement the knowledge of the distribution of microsporidia parasites among the honeybee and bumblebee populations all over the world (see Fig. 5).

Apian parasites of genus Nosema ( $N$. apis and N. ceranae) are wildly distributed in honeybee populations. Joint presence of these parasites was described in numerous studies (Table S1 in the Supplementary material) ${ }^{1}$. Nevertheless, there are cases in the several countries such as Indonesia, Israel, Kenya and Zimbabwe of honeybee infections by $N$. apis only (see Table S1). Presence of $N$. ceranae only was established in the honeybee's population from countries of Latin America (except Brazil), several European countries, Iran, Mongolia, Saudi Arabia and Vietnam (see Table S1). In this study, we discovered that honeybee populations were infected by $N$. ceranae. There were no cases of $N$. apis presence. Presence of $N$. bombi parasite in honeybee specimens was detected for the first time (see Fig. 5).

$N$. bombi is widespread in the natural and commercial bumblebee populations of North and South America, Eurasia and New Zealand (Gallot-Lavallée et al., 2016; Brown, 2017). Several N. bombi genetic variants (WS1, WS2 and WS3) were described in Siberian bumblebee populations (Vavilova et al., 2015). Four new Nosema variants (A, B, C and D) were isolated from bumblebees in China (Li et al., 2012). The microsporidian parasite, T. pampeana, was described in bumblebee populations from Argentina (Plischuk et al., 2015). In the recent decades the cases of bumblebees infection by apian

\footnotetext{
1 Supplementary materials are available in the online version of the paper:
} http://www.bionet.nsc.ru/vogis/download/pict-2017-21/appx15.pdf parasites N. ceranae (Argentina, China, Colombia, Mexico, UK and Uruguay), N. apis (Mexico and UK) and other $\mathrm{No}$ sema species (Chile, China and Mexico) have been described (Gallot-Lavallée et al., 2016; Brown, 2017). We established the presence of Nosema $D$ in bumblebee population from Jammu and Kashmir state (India). Nosema $D$ was previously described by (Li et al., 2012) (see Fig. 5).

Presence of two trypanosomatid parasites, C. mellificae and L. passim, was indicated in honeybee populations globally. C. mellificae was found in honeybee specimens from Australia, Belgium, USA and Spain (Table S2). L. passim infections were described for honeybees from Belgium, Japan, Serbia and Switzerland (see Table S2). In this study distribution of L. passim in Indian honeybee populations were established (see Fig. 5). There were no cases of honeybee infection by C. mellificae.

The cases of trypanosomatid infections were determined in commercial and native populations of bumblebees on the territories of North and South America and Eurasia. C. bombi is the most common trypanosomatid parasite that infects bumblebees from Argentina, Belgium, Chile, Germany, Italy, Russia, Switzerland and UK (Table S3). The second species C. expoeki is presented in Mexican and Swiss bumblebee populations (Schmid-Hempel, Tognazzo, 2010; Gallot-Lavallée et al., 2016). Bumblebee infection by C. mexicana was indicated in Mexico (Gallot-Lavallée et al., 2016). Both C. bombi and C. expoeki are distributed among bumblebee populations from India (see Fig. 5).

Thus, in this study the prevalence of Nosema, Crithidia and Lotmaria parasites in honeybee and bumblebee populations of Jammu and Kashmir and Karnataka states were identified. In addition, co-infection by Microsporidia and Trypanosomatidae parasites was identified in several honeybee and bumblebee specimens from Jammu and Kashmir state. Honeybee and bumblebee specimens from India studied were infected by several microsporidian parasites $(N$. bombi, N. ceranae and Nosema D). Trypanosomatid parasites of C. bombi, C. expoeki and L. passim species were detected in honeybee and bumblebee populations. Moreover, for the first time N. bombi infection was detected in the honeybee population. Thus, further investigations are required to determine distribution of microsporidia and trypanosomatid parasites among the honeybee and bumblebee populations all over the World.

\section{Acknowledgments}

The study was supported by the project 0324-2016-0008 from the Russian State Budget.

\section{Conflict of interest}

The authors declare no conflict of interest.

\section{References}

Arismendi N., Bruna A., Zapata N., Vargas M. PCR-specific detection of recently described Lotmaria passim (Trypanosomatidae) in Chilean apiaries. J. Invertebr. Pathol. 2016;134:1-5.

Brown M.J.F. Microsporidia: an emerging threat to bumblebees? Trends Parasitol. 2017;S1471-4922.

Brown M.J.F., Schmid-Hempel R., Schmid-Hempel P. Strong contextdependent virulence in a host-parasite system: reconciling genetic evidence with theory. J. Anim. Ecol. 2003;72:994-1002. 
Chen D., Shen Z., Zhu F., Guan R., Hou J., Zhang J., Xu X., Tang X., $\mathrm{Xu}$ L. Phylogenetic characterization of a microsporidium (Nose$m a$ sp. MPr) isolated from the Pieris rapae. Parasitol. Res. 2012;111: 263-269.

Chen Y.P., Huang Z.Y. Nosema ceranae, a newly identified pathogen of Apis mellifera in the USA and Asia. Apidologie. 2010;41:364-374.

Cordes N., Huang W.F., Strange J.P., Cameron S.A., Griswold T.L., Lozier J.D., Solter L.F. Interspecific geographic distribution and variation of the pathogens Nosema bombi and Crithidia species in United States bumble bee populations. J. Invertebr. Pathol. 2012; 109:209-216.

Cornman R.S., Tarpy D.R., Chen Y., Jeffreys L., Lopez D., Pettis J.S., vanEngelsdorp D., Evans J.D. Pathogen webs in collapsing honey bee colonies. PLoS ONE. 2012; 7:e43562.

Cox-Foster D.L., Conlan S., Holmes E.C., Palacios G., Evans J.D., Moran N.A., Quan P.L., Briese T., Hornig M., Geiser D.M., Martinson V., vanEngelsdorp D., Kalkstein A.L., Drysdale A., Hui J., Zhai J., Cui L., Hutchison S.K., Simons J.F., Egholm M., Pettis J.S., Lipkin W.I. A metagenomic survey of microbes in honey bee colony collapse disorder. Science. 2007;318:283-287.

Edgar R.C. MUSCLE: multiple sequence alignment with high accuracy and high throughput. Nucleic Acids Res. 2004;32:1792-1797.

Fantham H.B., Porter A. The morphology, biology and economic importance of Nosema bombi, N. sp., parasitic in various humble bees (Bombus spp.). Ann. Trop. Med. Parasit. 1914;8:623-638.

Felsenstein J. Phylogenies and the comparative method. Am. Nat. 1985;125:1-15.

Fries I., De Ruijter A., Paxton R.J., Da Silva A.J., Slemenda S.B., Pieniazek N.J. Molecular characterization of Nosema bombi (Microsporidia: Nosematidae) and a note on its sites of infection in Bombus terrestris (Hymenoptera: Apoidea). J. Apic. Res. 2001;40:91-96.

Fries I., Feng F., da Silva A., Slemenda S.B., Pieniazek N.J. Nosema ceranae n. sp. (Microspora, Nosematidae), morphological and molecular characterization of a microsporidian parasite of the Asian honey bee Apis cerana (Hymenoptera, Apidae). Eur. J. Protistol. 1996;32:356-365.

Gallot-Lavallée M., Schmid-Hempel R., Vandame R., Vergara C.H., Schmid-Hempel P. Large scale patterns of abundance and distribution of parasites in Mexican bumblebees. J. Invertebr. Pathol. 2016; 133:73-82.

Gatehouse H.S., Malone L.A. The ribosomal RNA gene region of $\mathrm{No}-$ sema apis (Microspora): DNA sequence for small and large subunit rRNA genes and evidence of a large tandem repeat unit size. J. Invertebr. Pathol. 1998;71:97-105.

Guindon S., Gascuel O. A simple, fast, and accurate algorithm to estimate large phylogenies by maximum likelihood. Syst. Biol. 2003;52: 696-704.

Han B., Weiss L.M. Microsporidia: obligate intracellular pathogens within the Fungal Kingdom. Microbiol. Spectr. 2017;5(2).

Higes M., Martín-Hernández R., Botías C., Bailón E.G., González-Porto A.V., Barrios L., Del Nozal M.J., Bernal J.L., Jiménez J.J., Palencia P.G., Meana A. How natural infection by Nosema ceranae causes honeybee colony collapse. Environ. Microbiol. 2008;10:2659-2669.

Hornitzky M. Nosema disease: Literature review and three year survey of beekeepers. Pt. 2. Rural Industries Research and Development Corporation, 2008.

Huang W.F., Jiang J.H., Chen Y.W., Wang C.H. A Nosema ceranae isolate from the honeybee Apis mellifera. Apidologie. 2007;38:30-37.

Langridge D.F., McGhee R.B. Crithidia mellificae n. sp.: An acidophilic trypanosomatid of honey bee Apis mellifera. J. Protozool. 1967; 14:485-487.

Larkin M.A., Blackshields G., Brown N.P., Chenna R., McGettigan P.A., McWilliam H., Valentin F., Wallace I.M., Wilm A., Lopez R., Thompson J.D., Gibson T.J., Higgins D.G. Clustal W and Clustal X version 2.0. Bioinformatics. 2007;23:2947-2948.

Li J., Chen W., Wu J., Peng W., An J., Schmid-Hempel P., SchmidHempel R. Diversity of Nosema associated with bumblebees (Bombus spp.) from China. Int. J. Parasitol. 2012;42:49-61.
Lipa J.J., Triggiani O. Crithidia bombi sp. n., a new flagellated parasite of a bumble bee Bombus terrestris L. (Hymenoptera, Apidae). Acta Protozool. 1988;27:287-290.

Liu H., Pan G., Li T., Huang W., Luo B., Zhou Z. Ultrastructure, chromosomal karyotype, and molecular phylogeny of a new isolate of microsporidian Vairimorpha sp. BM (Microsporidia, Nosematidae) from Bombyx mori in China. Parasitol. Res. 2012;110:205-210.

Malakauskas D.M., Altman E.C., Malakauskas S.J., Thiem S.M., Schloesser D.W. Ribosomal DNA identification of Nosema/Vairimorpha in freshwater polychaete, Manayunkia speciosa, from Oregon/California and the Laurentian Great Lakes. J. Invertebr. Pathol. 2015;132:101-104.

Martín-Hernández R., Botías C., Bailón E.G., Martínez-Salvador A., Prieto L., Meana A., Higes M. Microsporidia infecting Apis mellifera: Coexistence or competition. Is Nosema ceranae replacing Nosema apis? Environ. Microbiol. 2012;14:2127-2138.

Meeus I., De Graaf D.C., Jans K., Smagghe G. Multiplex PCR detection of slowly-evolving trypanosomatids and neogregarines in bumblebees using broad-range primers. J. Appl. Microbiol. 2010;109: 107-115.

Okonechnikov K., Golosova O., Fursov M., Varlamov A., Vaskin Y., Efremov I., Grehov G., Kandrov O.G., Rasputin D., Syabro K., Tleukenov M. Unipro UGENE: A unified bioinformatics toolkit. Bioinformatics. 2012;28:1166-1167.

Plischuk S., Sanscrainte N.D., Becnel J.J., Estep A.S., Lange C.E. Tubulinosema pampeana sp. n. (Microsporidia, Tubulinosematidae), a pathogen of the South American bumble bee Bombus atratus. J. Invertebr. Pathol. 2015;126:31-42.

Ravoet J., Maharramov J., Meeus I., De Smet L., Wenseleers T., Smagghe G., de Graaf D.C. Comprehensive bee pathogen screening in Belgium reveals Crithidia mellificae as a new contributory factor to winter mortality. PLoS ONE. 2013;8:e72443.

Runckel C., Flenniken M.L., Engel J.C., Ruby J.G., Ganem D., Andino R., DeRisi J.L. Temporal analysis of the honey bee microbiome reveals four novel viruses and seasonal prevalence of known viruses, Nosema, and Crithidia. PLoS ONE. 2011;6:e20656.

Schmid-Hempel P. On the evolutionary ecology of host-parasite interactions: Addressing the question with regard to bumblebees and their parasites. Naturwissenschaften. 2001;88:147-158.

Schmid-Hempel P., Reber Funk C. The distribution of genotypes of the trypanosome parasite, Crithidia bombi, in populations of its host, Bombus terrestris. Parasitology. 2004;129:147-158.

Schmid-Hempel R., Eckhardt M., Goulson D., Heinzmann D., Lange C., Plischuk S., Escudero L.R., Salathé R., Scriven J.J., Schmid-Hempel P. The invasion of southern South America by imported bumblebees and associated parasites. J. Anim. Ecol. 2014;83:823-837.

Schmid-Hempel R., Salathe R., Tognazzo M., Schmid-Hempel P. Genetic exchange and emergence of novel strains in directly transmitted trypanosomatids. Infect. Genet. Evol. 2011;11:564-571.

Schmid-Hempel R., Tognazzo M. Molecular divergence defines two distinct lineages of Crithidia bombi (Trypanosomatidae), parasites of bumblebees. J. Eukaryot. Microbiol. 2010;57:337-345.

Schwarz R.S., Bauchan G.R., Murphy C.A., Ravoet J., De Graaf D.C., Evans J.D. Characterization of two species of trypanosomatidae from the honey bee Apis mellifera: Crithidia mellificae Langridge and McGhee, and Lotmaria passim n. gen., n. sp. J. Eukaryot. Microbiol. 2015;62:567-583.

Smith M.L. The honey bee parasite Nosema ceranae: transmissible via food exchange? PLoS ONE. 2012;7:e43319.

Sokolova Y.Y., Sokolov I.M., Carlton C.E. Identification of Nosema bombi Fantham and Porter 1914 (Microsporidia) in Bombus impatiens and Bombus sandersoni from Great Smoky Mountains National Park (USA). J. Invertebr. Pathol. 2010;103:71-73.

Szentgyörgyi H., Blinov A., Eremeeva N., Luzyanin S., Grześ I.M., Woyciechowski M. Bumblebees (Bombidae) along pollution gradient - heavy metal accumulation, species diversity, and Nosema bombi infection level. Polish J. Ecol. 2011;59:599-610. 
Tamura K., Stecher G., Peterson D., Filipski A., Kumar S. MEGA6: Molecular evolutionary genetics analysis version 6.0. Mol. Biol. Evol. 2013;30:2725-2729.

Tay W.T., O'Mahony E.M., Paxton R.J. Complete rRNA gene sequences reveal that the microsporidium Nosema bombi infects diverse bumblebee (Bombus spp.) hosts and contains multiple polymorphic sites. J. Eukaryot. Microbiol. 2005;52:505-513.

Tritschler M., Retschnig G., Yañez O., Williams G.R., Neumann P. Host sharing by the honey bee parasites Lotmaria passim and Nosema ceranae. Ecol. Evol. 2017;7:1850-1857.

vanEngelsdorp D., Evans J.D., Saegerman C., Mullin C., Haubruge E., Nguyen B.K., Frazier M., Frazier J., Cox-Foster D., Chen Y., Under- wood R., Tarpy D.R., Pettis J.S. Colony collapse disorder: A descriptive study. PLoS ONE. 2009;4:e6481.

Vavilova V., Sormacheva I., Woyciechowski M., Eremeeva N., Fet V., Strachecka A., Bayborodin S.I., Blinov A. Distribution and diversity of Nosema bombi (Microsporidia: Nosematidae) in the natural populations of bumblebees (Bombus spp.) from West Siberia. Parasitol. Res. 2015;114:3373-3383.

Yourth C.P., Brown M.J.F., Schmid-Hempel P. Effects of natal and novel Crithidia bombi (Trypanosomatidae) infections on Bombus terrestris hosts. Insectes Soc. 2008;55:86-90.

Zander E. Tierische Parasiten als Krankenheitserreger bei der Biene. Münch. Bienenztg. 1909;31:196-204. 